\title{
The Impending Revolution in Undergraduate Science Education
}

\author{
Robert L. DeHaan ${ }^{1}$
}

There is substantial evidence that scientific teaching in the sciences, i.e. teaching that employs instructional strategies that encourage undergraduates to become actively engaged in their own learning, can produce levels of understanding, retention and transfer of knowledge that are greater than those resulting from traditional lecture/lab classes. But widespread acceptance by university faculty of new pedagogies and curricular materials still lies in the future. In this essay we review recent literature that sheds light on the following questions:

- What has evidence from education research and the cognitive sciences told us about undergraduate instruction and student learning in the sciences?

- What role can undergraduate student research play in a science curriculum?

- What benefits does information technology have to offer?

- What changes are needed in institutions of higher learning to improve science teaching? We conclude that widespread promotion and adoption of the elements of scientific teaching by university science departments could have profound effects in promoting a scientifically literate society and a reinvigorated research enterprise.

KEY WORDS: science education; cognitive science; undergraduate instruction; information technology; student research.

\section{INTRODUCTION}

At a recent meeting of officials of the US Department of Education and others dealing with science instruction in the nation's schools and colleges (Secretary's Summit on Science Education, March 16, 2004, Washington, DC), physics Nobelist Carl Wieman made an impassioned plea for improved teaching in science at the undergraduate level. He called for instructional settings in which students can do more problem solving and have greater opportunities to do real science: "using the tools of science to teach science". Wieman was referring to a kind of instruction, termed "scientific teaching," that research has shown "involves active learning strategies to engage students in the process of science, and teaching methods that have been systematically tested and

\footnotetext{
${ }^{1}$ Emory University, Division of Educational Studies, North Decatur Building, Rm. 254, 1784 N. Decatur Road, Atlanta, Georgia 30322; e-mail: rdehaan@emory.edu
}

shown to reach diverse students" (Handelsman et al., 2004, p. 521).

We now have a substantial body of evidence that instructional strategies in science that encourage undergraduates to become actively engaged in their own learning - i.e. scientific teaching-produce levels of understanding, knowledge retention and transfer that are greater than those resulting from traditional lecture/lab classes. The evidence for this finding from college classrooms and teaching experiments across the country is accumulating rapidly. But widespread acceptance by university faculty of new pedagogies and curricular materials still lies in the future. Here we highlight recent research in the cognitive sciences, instructional methods, student learning, educational policy, and assessment designed to shed light on the following questions:

- What has recent evidence from education research and the cognitive sciences told us about undergraduate instruction and student learning in the sciences? 
- What role can undergraduate student research play in a science curriculum?

- What benefits does information technology have to offer?

- What changes are needed in institutions of higher learning to improve science teaching?

We begin with a brief historical background, and then-with no effort to achieve a comprehensive review-proceed to outline some of the recent contributions to the research literature that shed light on each question raised.

\section{BACKGROUND}

The view that strategies and curricula for teaching science can be subjected to rigorous experimental testing for effectiveness has a long history (reviewed in McDermott, 1991; Redish, 1999). Such studies have served as the basis for what has come to be called the science education reform movement, calling for a switch from traditional lectures and workbook labs, to scientific teaching strategies. Beginning in a few centers of science education research, the movement is now supported by organizations such as the National Science Foundation, the National Science Resources Center, the National Science Teachers Association, the National Institutes of Health, and many scientific professional societies.

Forces pressing for change in science education have come from many sources, not only the scientific and educational communities. The corporate world is equally concerned because of rapidly changing workforce needs that have become apparent in recent decades. Although the population of American undergraduates that earned bachelor's degrees in science and engineering (S\&E) has remained constant at about $32 \%$ for the past three decades or more (Mervis, 2003; National Science Board, 2004), demand for scientifically and technically trained workers has soared. A panel of the National Academies' Government-University-Industry Research Roundtable concluded that the US faces "a crisis in S\&E talent and expertise" (NRC, 2003c, p. 5) because we are not graduating a sufficient supply of scientific and technical talent to fill the jobs available in the country's laboratories, defense installations and high-tech industries. According to the National Science Board (NSB, 2004) the number of jobs in the US labor force requiring $\mathrm{S} \& \mathrm{E}$ skills is growing at the rate of almost $5 \%$ while the rest of the labor force is growing at just over $1 \%$. The solution to this problem lies in several strategies: making "a quality education in math and science a priority" (NSB, 2004, p. 3); providing better S\&E education for the nation's youth; and steering a larger fraction of them into scientific and technical fields. To accomplish that end, the NRC's Government-University-Industry Research Roundtable concludes that we must

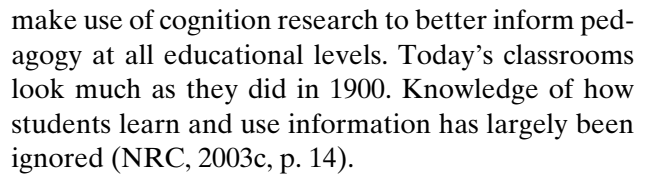
agogy at all educational levels. Today's classrooms look much as they did in 1900 . Knowledge of how students learn and use information has largely been ignored (NRC, 2003c, p. 14).

According to a comprehensive study by Seymour and Hewitt (1997), a loss of over half of the students who enter college intending to pursue majors in the natural sciences occurs within two years of taking their first college science class, a problem of wastage that affects both minority and majority students. Students reported being dissatisfied with what they perceived as poor teaching and other negative experiences in "weed-out" science courses. Frequent complaints were heard about classes and textbooks that are filled with isolated facts that students are expected to memorize with little opportunity for conceptual development, and tests that assess little more than students' ability to remember such facts from recent lectures and chapters. Rather than subjecting undergraduates to introductory courses that are designed to select a limited number of future scientists while alienating the majority, students in lower division science curricula should be offered "learning experiences that motivate them to persist in their [scientific] studies and consider careers in these fields" (Project Kaleidoscope, 2002, p. 1).

Despite such recommendations from experts in the field, a broad survey of 123 research-intensive (Research I and II) universities nationwide by The Reinvention Center at Stony Brook (2001), found that only small numbers of the students on about $20 \%$ of these campuses have opportunities for active learning or real-world problem solving in their introductory science courses. On a majority of campuses the instructor as an information-delivering lecturer remains typical practice in science courses. Although it is widely recognized in the psychology literature that lectures may be valuable vehicles for information transfer, they tend to promote memorization rather than conceptual understanding (Bligh, 2000; Novak, 2002). Nonetheless, traditional lecture courses predominate. As noted by Alison King (1994), "Much of what transpires in today's 
college classrooms is based on the outdated transmission model of teaching and learning: the professor lectures and the students take notes, read the text, memorize the material, and regurgitate it later on an exam" (p. 15). This is a model that is not likely to increase the numbers of students attracted to careers in science or to help them become scientifically literate citizens.

\section{WHAT HAS RECENT RESEARCH IN EDUCATION AND THE COGNITIVE SCIENCES TOLD US ABOUT UNDERGRADUATE INSTRUCTION AND STUDENT LEARNING IN THE SCIENCES?}

Questions about how students are taught and what they learn in college science courses have occupied educators for many years (e.g. Dwyer, 1972; Arons, 1983). From the influential report, A Nation at Risk (National Commission on Excellence in Education, 1983) with its "Imperative for Educational Reform," to the Boyer Commission (1998) and Glenn Commission (2000) studies, to the present, reports by the dozens, from individual experts and a welter of national associations, blue-ribbon panels and accrediting boards have called for improved science education in our nation's schools and colleges. Appearing over many years, at the rate of almost one a week during some periods according to Tobias (1992), these reports have been notable for their convergence on certain ideas. Among the most thoughtful and best documented of such studies is a series of reports by panels brought together under the auspices of the National Research Council, an arm of the National Academies (National Research Council, 1997, 1999a,b, 2000, 2002a,b, 2003a,b). Virtually all these expert sources agree that science education should focus: less on what instructors "cover," and more on what students learn and how well they can use their knowledge; less on vocabulary and facts that students memorize, and more on students' understanding of scientific concepts and how those concepts fit together in a framework of knowledge about a subject; less on what students can repeat back immediately in class, and more on their long-term retention and ability to transfer their knowledge to contexts outside the classroom. These generalizations have been condensed into lists of educational principles by several workers.

\section{Principles of Learning}

To enhance students' long-term retention and transfer of knowledge, research in the learning sciences has led to a number of insights that are grounded in evidence and widely cited in the above reports. In his 1998 Millikan Lecture, physics educator E. F. Redish (1999) articulated five general principles based upon results from psychologists and education researchers, principles that he believed could help make sense of what happens in the physics classroom. He has since incorporated these ideas into a well-regarded text: Teaching Physics with the Physics Suite (Redish, 2003, pp. 30-39).

(1) The constructivism principle: Individuals build their knowledge by processing the information they receive, building patterns of association to existing knowledge.

(2) The context principle: What people construct depends on the context-including their mental states.

(3) The change principle: Producing significant change in a well-established pattern of associations is difficult but can be facilitated through a variety of known mechanisms.

(4) The distribution function principle: Individuals show a limited but significant variation in their style of learning along a number of dimensions.

(5) The social learning principle: For most individuals, learning is most effectively carried out via social interactions.

Much of the evidence that supports such principles was elaborated in an NRC report, How People Learn: Brain, Mind, Experience and School (NRC, 2000), written under the supervision of a committee that included education researchers, teachers, psychologists, and cognitive scientists. The major findings from this book-length study on the "learning sciences" have been condensed into a list of seven "Principles of Learning" (NRC, 2003a, pp. 20-22) that differ slightly from but largely overlap Redish's list, as follows:

(1) Learning with understanding is facilitated when new and existing knowledge is structured around the major concepts and principles of the discipline. Experts' content knowledge is structured around the major organizing principles, core concepts, and "big ideas" of the discipline. Therefore, it is 
not adequate for a student to learn many disconnected facts about a subject. Curricula that emphasize simple recall of factual information over a wide variety of topics within a discipline do not help students organize knowledge effectively. Students who fail to learn facts and concepts in depth are not able to structure what they are learning around the major organizing principles and core frameworks of the discipline.

(2) Learners use what they already know to construct new understandings. College students have knowledge, skills, beliefs, concepts, conceptions, and misconceptions that influence how they think about the world, approach new learning, and go about solving unfamiliar problems. Learning a new idea or process requires relating it to ideas or processes they already understand. This prior knowledge can produce mistakes as well as new insights. Learners are likely to create mental constructs around newly encountered problems and phenomena that agree with their prior knowledge even when those interpretations conflict with what a teacher has attempted to teach. Therefore, effective teaching involves gauging what learners already know about a subject and finding ways to build on that knowledge. When prior knowledge contains misconceptions, effective instruction entails detecting those misconceptions and addressing them, sometimes by challenging them directly.

(3) Learning is facilitated through the use of metacognitive strategies that identify, monitor, and regulate cognitive processes. Metacognitive strategies include (a) connecting new information to former knowledge; (b) selecting thinking strategies deliberately; and (c) planning, monitoring, and evaluating thinking processes. To be effective problem solvers, learners must consider both factual knowledge-about the task, their goals, and their abilities-and strategic knowledge about how and when to use a specific procedure to solve the problem at hand. Instructors can facilitate the development of metacognitive abilities by offering explicit instruction focused on such skills, by providing opportunities for students to observe teachers or other content experts as they solve problems, and by making their thinking visible to students with whom they work.

(4) Learners have different strategies, approaches, patterns of abilities, and learning styles that are a function of the interaction between their heredity and their prior experiences. Among any group of learners, there are important individual differences in cognitive abilities as well as in emotional, cultural, and motivational characteristics. Educators need to be sensitive to such differences so that instruction and curricular materials will be suitably matched to students' developing abilities, knowledge base, preferences, and styles. Students with different learning styles also need a range of opportunities and ways to demonstrate their knowledge and skills. Using a single form of assessment often works to the advantage of some students and to the disadvantage of others. Multiple measures of learning and understanding provide a better picture of how well each student is achieving the learning goals.

(5) Learners' motivation to learn and sense of self affect what is learned, how much is learned, and how much effort will be put into the learning process. Both internal and external factors motivate people to learn and develop competence. Intrinsic motivation is enhanced when students perceive learning tasks as interesting and personally relevant, and when they are presented at an appropriate level of difficulty. Tasks that are too difficult can frustrate; those that are too easy can lead to boredom. Moreover, there are strong connections between learners' beliefs about their own abilities in a subject area and their success in learning that subject. Instructional strategies that are supportive and encourage conceptual understanding increase students' interest and enhance their confidence about their abilities to learn a particular subject.

(6) The practices and activities in which people engage while learning shape what is learned. When students learn subject matter or concepts in only a limited context, they often miss seeing the applicability of that information to other situations. By encountering a given concept in multiple contexts, students develop a deeper understanding of the concept and how it can be used and applied 
to other contexts. Problem-based and casebased learning are two instructional approaches that create opportunities for students to apply knowledge in multiple realworld contexts and to engage in practices similar to those of experts. These strategies also provide opportunities for instructors to help students understand when and how to transfer new concepts and skills to different situations. Technology also can serve as a vehicle to bring real-world contexts into the learning environment through the use of authentic information sources and databases.

(7) Learning is enhanced through socially supported interactions. In learning environments that encourage collaboration, such as those in which most practicing scientists and mathematicians work, individuals have opportunities to test their ideas and learn by observing others. Providing students with opportunities to articulate their ideas to peers and to hear and discuss others' ideas in the context of the classroom is particularly effective in enhancing conceptual learning. Social interaction also is important for the development of expertise, metacognitive skills (see learning principle \#3), and formation of the learner's sense of self (see learning principle \#5).

From a similar review of research, Halpern and Hakel (2003) cite their own list of 10 principles that they conclude should guide student behavior during a learning experience. These again resemble and overlap those on the previous lists.

Learning and conceptual understanding are enhanced by the following.

(1) Repeated practice at retrieval of information over time with varied applications.

(2) Varying the conditions under which learning takes place by, for example, mixing different types of problems and solutions in the same lesson or unit.

(3) Re-representing information in both auditory-verbal and visuo-spatial formats.

(4) Explicitly integrating new information into prior conceptual frameworks.

(5) Articulating clear learning goals.

(6) Recognizing that learning is a function of what the learner does, not the instructor.

(7) Examining implicit beliefs about learning and self-efficacy.
(8) Remembering that confidence about prior knowledge is not well correlated with validity.

(9) Acknowledging that lectures foster rote memorization, not conceptual learning.

(10) Understanding that the act of remembering strengthens some memory traces and quenches others.

What kinds of primary evidence warrant such broadly acknowledged views as the principles listed above? Education research from a wide variety of instructional venues that spans ethnographic approaches, quantitative experiments and quasiexperiments, as well as developmental psychology and the cognitive neurosciences, has provided many of these insights into teaching and learning.

\section{The Evidentiary Base}

With no effort at a comprehensive review of the extensive bodies of literature that have appeared in recent years, we describe here examples of some of the critical evidence that supports these learning principles. A sampling of studies centered on ethnographic analysis of student experiences, classroom quasi-experiments, and neurocognitive investigations is described below.

\section{Individual Case Studies}

Interviewing and observing individual students can often provide substantial insight into how they learn and what barriers prevent learning. We now understand from studies in fields such as linguistics (Gordon, 2004; Pica et al., 2004) and discourse analysis (e.g. Gee, 1999) that language is not simply a medium to communicate thoughts. Rather, it is an active determinant of understanding. Learners do not build internal mental models of the world independent of the language necessary to express those models. Learning new vocabularies and ways to express concepts must be seen as an interactive whole with creating the concepts themselves (see e.g. Roth and Duit, 2003; Gee, 2003; Gelman and Gallistel, 2004). Redish (1999) describes an example to demonstrate that listening carefully to what one student says in a detailed interview can help substantially in understanding student learning and, by extension, the effectiveness of an instructional strategy. As part of a project to develop instructional materials for the subject of mechanical waves, Redish and his colleagues 
analyzed responses of their engineering physics students to quiz problems. Through in-depth interviews, they asked students to consider the problem and explain their reasoning. They found that focusing on how a small number of students constructed their responses helped unravel unrealized instructional inadequacies. In another example, careful analysis of student expressions concerning their classroom experiences clarified how difficult it is for even postsecondary students to comprehend the difference between construction of their own knowledge and memorization of transmitted information. Similar attention to the perceptions of individual students has convinced many investigators to become strong advocates for integrating constructivist pedagogies into university courses (e.g. Schwartz and Fischer, 2003; Handelsman et al., 2004).

\section{Classroom Studies}

Efforts at improving science courses first began in physics in the 1970s, initially focused on education programs for pre-service teachers (McDermott, 1974). With the appearance of several physics education research efforts such as the "Studio Physics" group at Rensselaer Polytechnic Institute (http://www.rpi.edu/dept/phys/education.html) and the Physics Education Group at University of Washington (http://www.phys.washington.edu/ groups/peg/) (see Laws, 1997; McDermott and Redish, 1999; McDermott, 2001) knowledge about physics teaching began to accumulate in a systematic and progressively more effective way. Progress accelerated after a test for student conceptual understanding, the Force Concept Inventory (FCI) was developed by David Hestenes and his collaborators at Arizona State University (Hestenes et al., 1992). Now widely used and modified, the FCI at first generated substantial controversy among physics faculty because the test questions appeared to their eyes to be trivial and easily answered by all but the most backward students. The discovery that students in fact did poorly — generally less than $60 \%$ - even after completing a calculus-based course, shocked many instructors. In the early 1990s, Richard Hake of Indiana University, collected data on pre-post FCI results from faculty that were teaching introductory physics courses at universities around the country, along with descriptions of the courses given (Hake, 1998). Covering 62 semester-long classes averaging about 100 students each, Hake found a strong correlation between students' measured conceptual gains and their degree of active engagement in the learning process. Fourteen of these were "traditional" courses consisting of standard lectures and workbook laboratories with little or no opportunity for interactiveengagement of students. In sharp contrast, 48 courses made substantial use of active engagement methods, with opportunities for students to work through the logic of problems and even perform small experiments to test physical concepts. Hake found that students in the latter courses averaged gains that were twice as large as those in the traditional classes (Hake, 1998, 2002). Results consistent with these have since been obtained by numerous other physics research groups (Ambrose et al., 1999; Redish, 2003; Heron et al., 2003; Loverude et al., 2003). Interactive engagement of students in their own learning measurably enhanced the conceptual development and problem-solving abilities of the learners.

Active learning strategies have been adapted to other disciplines with variable success. Stimulation of deeper learning and understanding as well as increased motivation and enthusiasm for the subject have been achieved in classes from 40 to 400 students by scientific teaching strategies in fields as disparate as astronomy (Powell, 2003), genetics (Pukkila, 2004), and chemistry (Wright et al., 1998; Berg et al., 2003). The University of Oregon's Workshop Biology curriculum (Udovic et al., 2002) became one of several experimental teaching approaches in the life sciences that succeeded during the 1990s in enhancing students' conceptual learning, attitudes toward science, and problem solving capacities (see also Ebert-May et al., 1997; Lawson, 2003). Taking physics as an example, it is expected that the spread of active learning pedagogies through other sciences will be accelerated by the development of instruments comparable to the FCI, designed to measure student comprehension of concepts deemed to be important for understanding each of the scientific disciplines. An initial version of a Chemistry Concepts Inventory (CCI) has appeared (Mulford and Robinson, 2002), and a collaborative effort to create a Biological Concept Inventory (BCI) is currently underway (Klymkowsky et al., 2003).

\section{Neuro-Cognitive Research on Learning}

It is intuitively obvious that cognition is both a psychological and a neuronal phenomenon. For example, learning depends upon memory-how information is stored in the brain. We now know that memory is a complex system of neuronally 
supported functions distributed widely in various anatomical circuits in different parts of the brain (Kandel et al., 2000; Miyashita, 2004). Memory is divided into two kinds, short-term (working) memory and long-term (Damasio, 1999). Long-term is further sub-divided into explicit (declarative) and implicit (or non-declarative) components. Working memory is fast but limited in capacity; information tends to fade after a few seconds. Long-term memory can hold large amounts of information and maintain it for years. Using information from long-term memory requires a process of activation whereby it is brought into working memory. This activation is "associative," that is it requires assembling or re-assembling various small units of stored information. Some of the learning principles listed above derive from experimental research on memory and its relationship to knowledge utilization and transfer. The connection between neurocognitive research and its application in the classroom has been explored in a number of studies (e.g. NRC, 1999a, 2000; Redish, 2003, Chapter 2). Although cautions have been raised about making too much of "brain-based" learning (Breuer, 1997), specific pedagogical practices have been shown to help students learn cognitive and metacognitive strategies that can lead to meaningful incorporation of new knowledge. Such "meaningful learning" takes place when learners choose conscientiously to integrate new knowledge into knowledge they already possess (Novak, 2002). Such strategies would include knowing how to integrate new information and concepts with their preconceptions, how to organize knowledge in ways that facilitate retrieval and application, how to define their own learning goals and monitor their progress toward achieving them, and how to apply their knowledge in new contexts.

In addition to memory, learning is affected dramatically by motivation to learn, termed "orientation" toward learning (Donald, 2002). There is a large body of convincing data that students can take either a deep orientation, in which they are highly motivated to learn and seek to relate to and maximize understanding of new knowledge, or a superficial orientation which, in contrast, involves little motivation and results mainly in rote memorization (Novak, 2002). Donald (2002, p. 5) argues that students may adopt either a deep or superficial orientation, depending upon socially constructed cues given by the instructor. Research on the neural basis of motivation and reward in humans and animal models is now an active area of study by neurobiologists using combinations of psychophysical, electrophysiological, neuroanatomical and molecular methods to identify neurons or neural pathways active in specific behaviors. There are roughly 100 billion neurons in the human brain, and each one may be connected to thousands of others. At any moment, many neurons are active simultaneously, enabling information signals to flow in many directions at once, establishing patterns of connectivity (Damasio, 1999; Koch and Laurent, 1999). Changes in motivation and other neurocognitive processes have been shown to depend on neurons with different patterns of connectivity, whose activities are mediated by diverse neurotransmitters. For example, the elements of goal-setting, intimately related to motivation, can be studied in active, alert experimental animals by decoding "cognitive signals" arising from individual neurons. The intention to reach for an object, the intended direction of a hand-reach, even the decision to reach for one object over another determined by a prior preference can be analyzed with such techniques (Musallam et al., 2004).

As now often reported in the lay press (e.g. Deardorf, 2004), both motivation to learn and such processes of mentation as attention and memory can be enhanced pharmacologically (Chattterjee, 2004). Recent studies analyze the mechanisms of drugs known as memory enhancers that appear to produce their results (thus far only in laboratory animals) through activation of a nuclear protein known as Cyclic-AMP Response Element Binding protein (CREB). Activated CREB is known to switch on genes in neural cells whose protein products strengthen synapses involved in long term memory (Hall, 2003; Tully et al., 2003). This enhancement of synaptic function is an essential component of learning. Although experimental evidence is not yet available, it is at least worth speculating that a teacher who switches a student from a superficial to a deep orientation toward learning may be entraining a mechanism that has something to do with activation of CREB.

A growing body of science educators has found that students' attitudes toward science, their motivation for learning, and their conceptual development in the discipline can all be enhanced by engagement in real scientific investigations. This has led to programs on many campuses in which a research experience in a supportive community that includes one or more instructors to provide guidance is built into the curriculum for all science majors. In some cases, an 
effort is made to offer these experiences to a larger range of students, even those taking lower division science courses but who are not majoring in the sciences. Thus, it is useful to consider what impact such programs have had.

\section{WHAT ROLE CAN UNDERGRADUATE STUDENT RESEARCH PLAY IN A SCIENCE CURRICULUM?}

It is widely held that students can benefit in their learning of science if they have opportunities to $d o$ science through either in-class science projects or extracurricular work with scientists (NRC, 1999b, 2002a, 2003a,b). Science educators have long held that working on authentic science research projects facilitates the development of scientific literacy by enhancing students' understandings of science content, the strategies and logic of scientific inquiry, and the nature of science. Hodson (1993) explained that "one cannot learn to do science by learning a prescription or set of processes to be applied in all situations. The only effective way to learn to do science is by doing science..." (p. 120). By engaging in the messiness of science investigationshowever limited they might be-it is hoped that students would go beyond learning science content to learning how to think like a scientist. Involvement in scientific inquiry can range from relatively brief classroom activities to lengthy apprenticeship projects in research laboratories. They can engage students with real materials or with virtual problemsolving environments. DebBurman (2002) engages students in "mock experiential research projects" that entail role playing in such activities as giving a journal club report, writing a medical news article, presenting an oral seminar, and writing a lab report. It is generally believed that the more authentic the research experience, such as an apprenticeship guided by a science professional, the more students will learn about scientific inquiry and the more positive will be their feelings toward science. However, resources for providing such experiences to large numbers of students may be unavailable.

In accordance with these views, a variety of programs have sought to place students in research laboratories or special programs intended to allow them to develop broader and more complete understandings of the scientific enterprize through participation in authentic science experiences. Many of these efforts are described in a recent review of published articles and evaluation reports that address the benefits of undergraduate research (Seymour et al., 2004). To establish what is known about the qualities and effects of student research programs, the authors defined a typology that divided the literature into two main types: (1) papers and reports in which the hypothesized benefits of undergraduate research are tested and well supported, and (2) papers and reports in which benefits are simply stated or claimed but not adequately demonstrated. Out of a total of 54 publications examined, $83 \%$ fell into the second category, in which hypothesized benefits were not convincingly demonstrated, either because of design limitations or because methods were incompletely described. Nine reports, consisting of four research papers and five evaluation studies, provided convincing evidence of benefits to students, including gains in basic research and oral communication skills, understanding of the nature and development of scientific knowledge, and epistemological development from simplistic to complex ways of knowing. Skills that students felt were enhanced by their research experiences included observing and collecting data, communicating research results orally, relating results to the "bigger picture," and understanding contemporary concepts in the field. For example, the author of one of the nine studies that met the standards of Seymour and her colleagues (Kardash, 2000) concluded that undergraduate research experiences were successful in enhancing a list of basic scientific skills. The evidence was less compelling in this study that such experiences promoted the acquisition of higher-order thinking skills such as identifying a specific question for investigation or designing a test of a hypothesis, skills that underlie critical scientific reasoning.

In a further interview study of 76 undergraduates from four college campuses who had participated in a 10 -week summer research program as rising seniors, Seymour et al. (2004) found that the students were overwhelmingly positive about their experience: $91 \%$ of all statements referenced gains of various kinds. Among the most prevalent of these were: increased confidence in their ability to do research; improved ability to think and work like a scientist; gains in various skills such as problem solving, lab/field techniques, reading comprehension, working collaboratively; clarification/confirmation of career plans, and shifts to more positive attitudes toward learning or toward research.

Many colleges and universities have joined in the effort to engage larger numbers of students in a research experience. Justifications offered by various 
institutions include the increasingly multidisciplinary nature of scientific investigations; the changing demographics of students and faculty members; the increasing desire to integrate research more fully throughout the curriculum; and the expanding recognition that student research may actually improve student learning. National organizations have sprung up to further this trend. Two of these are the Council on Undergraduate Research (CUR) and the National Conference on Undergraduate Research (NCUR). CUR and its affiliated colleges, universities, and individual members focuses on promoting student research opportunities at predominantly undergraduate institutions. They provide publications and outreach activities that are designed to share successful models and strategies for establishing and institutionalizing undergraduate research programs, and to assist administrators and faculty members in improving and assessing the research environment at their institutions. CUR has 3,000 members representing over 870 institutions (www.cur.org). NCUR (www.ncur.org), as its name implies, focuses primarily on its annual conference, through which the organization attempts to encourage awareness of undergraduate research, scholarship, and creative opportunities as they exist in various disciplines and types of institutions.

The National Science Foundation is also a supporter of undergraduate research. In 2003, the NSF funded an Undergraduate Research Summit that brought together an array of stakeholders, including public and private undergraduate and doctoral-granting institutions, and representatives of industry, national laboratories, and funding agencies. (Report at: http://abacus.bates.edu/acad/depts/chemistry/twenzel/ summit.html.) Discussion at the meeting was facilitated by a series of white papers that addressed topics such as defining and assessing undergraduate research, the value of diversity within the chemical sciences, and designing a researchsupportive curriculum. These can be accessed at (http://abacus.bates.edu/acad/depts/chemistry/ twenzel/ white_papers.html). Although the meeting focused on research in the chemical sciences and was attended mainly by chemists, many of the recommendations contained in the report apply more broadly across all science disciplines.

A vexing problem in the move to provide genuine research experiences for students is that it is costly. It is time-intensive for instructors, it consumes classroom or laboratory space, and it places demands on other departmental equipment and facilities. Some of these costs can be offset by employing undergraduates as student research assistants. This strategy has the distinct advantage that it can provide a direct pathway for a limited number of students to a scientific career (e.g. Silva et al., 2004). However, it cannot solve a second problem, which is how to afford a research experience to non-majors, or to the growing number of students engaged in classes taken through distance learning programs who never-or only occasionally - assemble in a classroom face to face with an instructor? To many, the search for solutions to these difficulties has become urgent because of the growing recognition that student research experiences should be an important component of a well-rounded science curriculum (NRC, 2002a, 2003a,b). Some workers argue that solutions to such problems will come from the expanded utilization of information technology.

\section{WHAT BENEFITS DOES INFORMATION TECHNOLOGY (IT) HAVE TO OFFER IN SCIENCE EDUCATION?}

In a chapter entitled "The complexity of coming to know," Laurillard (2002) catches herself "wishing I could attach electrodes to students' heads to see what goes on when they learn" (p. 41). The issue she grapples with is how to form a bridge between what we know about how students learn and what we should do as teachers. If we are persuaded by the evidence cited above that telling students what they need to know about a subject via lectures is not an optimal instructional strategy; if we are convinced that it leads at best to memorization of facts and algorithms, with little integration of new knowledge into the students' conceptual frameworks, then we must seek newer strategies that have been shown to help students achieve meaningful learning and transferable knowledge.

Accumulating evidence suggests that such strategies are available through IT-based learning (Laurillard, 2002; Strangman and Hall, 2003; Twigg, 2003). The adaptive and interactive nature of computer software affords instructors and curriculum designers advantages over traditional instructional approaches: (1) students can examine ideas and concepts that may be inaccessible with traditional teaching strategies through exploration, experimentation and modeling; (2) teaching/learning strategies can be highly individualized for each student; 
(3) assessment of student learning is readily built into the instructional materials; and (4) educational activities can be expanded beyond classrooms to workplaces, homes, and community settings.

Educators currently have available a wide variety of devices, media, and virtual contexts enabled by sophisticated information technology. The following is only a partial list (Dede, 2000; NRC, 2002b; Twigg, 2003; Whatley, 2004): (1) virtual reality and computer simulation software to support design, problem solving, and decision-making; (2) cognitive audit trails for automatic recording of user actions to support performance assessments; (3) intelligent tutors and software coaches to provide embedded expertise for greater individualization; (4) optical-disc systems with multiple read/write and mixed media capabilities to support large databases, inexpensive data storage, and shared distributed virtual environments; (5) standardized computer and telecommunication protocols for ready connectivity and compatibility; (6) authoring and user interface systems for development of readily mastered applications; (7) sophisticated cognitive modeling software based on an extensive literature of theory and experimentation.

\section{IT-Based Software to Enhance Instruction}

Computer-based simulation and virtual reality software have been shown to improve three major learning outcomes: conceptual change, skill development, and content area knowledge (Strangman and Hall, 2003). Such programs can also afford modeling environments and access to authentic research data that offer potential for breakthroughs in science learning in the classroom and in distributed learning contexts. Computer models offer students opportunities to gain both subject matter knowledge and metacognitive skills, and help them visualize scientific concepts that are not observable in real life. For example, students can use a model of atoms and a temperature sensor to visualize and better understand the connection between temperature and the motion of atoms. Carl Wieman, at the University of Colorado at Boulder, has devised simple computerbased lab exercises designed to help students visualize what would otherwise be abstract concepts in physics (www.colorado.edu/physics/phet/simulationpages/simulation-index.htm). One of the programs shows the build-up of static electricity when students rub the foot of dancer 'John Travoltage' across a carpet. Another gets students to build a circuit using a battery, switch, light bulb and resistors. The unique aspect of such teaching modules is that when the switch is thrown, the program illustrates the flow of electrons, allowing the students to visualize concepts in the same way that a trained physicist does (Powell, 2003).

Cognitive modeling can range widely in complexity, from support mechanisms for organizing concepts, to environments that allow students to construct objects in their own microworld. Technology for concept mapping (http://cmap.ihmc.us/) coupled with strategies such as problem-based learning (Duch et al., 2001; Allen and Tanner, 2003a) engage students in metacognitive work and greatly enhance their ability to represent knowledge in new forms (Fisher, 2000; Novak, 2002; Allen and Tanner, 2003b). Modeling also refers to simulation programs that allow users to construct models of some aspect of reality (e.g. Edwards, 1996; Laurillard, 2002; Strangman and Hall, 2003). Model construction projects and virtual worlds can teach by abstraction and problem-solving (Horwitz, 1999; Ogborn, 1999; Spitulnik et al., 1999; Roussev and Rousseva, 2004).

\section{Technology-Based Innovations for the Classroom}

New and existing technologies such as graphing calculators, word processors, digital cameras, and the Internet have enormous potential for teaching with new strategies. One challenge is helping instructors understand how to use these devices effectively with their students, even in small classes of 30 students. Thinking of ways to make a 200-person course seem more student-centered may be an even greater challenge (Crouch and Mazur, 2001; EbertMay et al., 1997; Wood, 2003; Pukkila, 2004). The technological solution advocated by astrophysicist Richard McCray involves a classroom response system that arms each student with a "clicker," i.e. a wireless classroom communication device that resembles a television remote control. Growing in popularity on numerous college campuses, such systems are now offered by several vendors (e.g. www.einstruction.com; http://he-cda.wiley. com/WileyCDA/Section/id-103701.html). During class, the instructor poses questions to which students respond using their clickers (Woods and Chiu, 2003). The responses are collected by a receiver, and instantly analyzed and displayed on computer screens visible to both the students and instructor. In the lecture room, rather than lecturing, McCray separates a class of 200-400 students into "teams" and asks each team to work on a problem. Team members have electronic clickers so that McCray can 
take a problem that has stumped many teams, turn it into a multiple-choice question, and ask everyone to vote on it. This instant feedback allows him to see if a common misconception has tripped up his students - and if so, to dispel it rapidly (Powell, 2003). Not all students enjoy learning in this way. Some complain about the lack of a lecture. Almost all find themselves outside their comfort zone; they miss being told what to learn. But when pressed, many admit that they remember more from the astronomy course than from other, lecture-based courses, an impression corroborated by a course evaluation, which also shows that students are electing McCray's course over others (http://www.colorado.edu/ATLAS/ evaluation/edt/iastron.html). Eric Mazur now uses similar methods as an alternative to lectures at Harvard University. In a strategy he terms "Peer Instruction" (Mazur, 1997), he asks students to interrogate each other, struggle with a problem, predict the answer, and then try to convince their neighbor of their argument (Crouch and Mazur, 2001). As noted above, there is convincing evidence that such strategies for transforming passive lecture classes into more student-centered, inquiry-based experiences for students usually elicit more and deeper learning (Hake, 1998; Crouch and Mazur, 2001; Dancy and Beichner, 2002).

\section{Access to Databases}

IT-based instruction offers another advantage; it can be structured around original sources of scientific data that span traditional disciplinary boundaries. Genetics, for example, is a particularly difficult topic to teach because it involves complex, interrelated, mostly unobservable processes that occur at different levels: molecular, cellular, and organismal, and that require quantitative analysis. Adding to these difficulties is the fact that genetics is frequently taught in large lectures as a component of a lower division, large-enrollment course. A variety of pedagogical strategies can be used to make such courses more student-centered (Pukkila, 2004). Moreover, by showing students how to use original databases such as GenBank (http://www. ncbi.nlm.nih.gov/Genbank/index.html) or the Human Genome Browser (http://genome.ucsc.edu/cgibin/hgGateway?org=human), they can have access to genome sequences, genomic variations within the population, gene expression patterns, protein expression patterns, protein interactions, and other genomic data. With careful instruction undergraduates can learn how to work with such information for authentic explorations of scientific concepts. The BioQuest Consortium is an organization that provides innovative materials designed to encourage the use of simulations, databases, and computational tools to construct learning environments where students are able to engage in activities like those of practicing scientists. Spearheaded by John Jungck at Beloit College, BioQuest (www.bioquest.org) has established a solid track record for using real data in conjunction with a case-based approach to assist students in increasing their quantitative sophistication, improving problem solving skills and enhancing conceptual development.

\section{Individualized Instruction On-Line}

A fundamental premise of many advocates of IT-based programs is that meaningful learning can be attained through greater individualization of learning experiences for students (Twigg, 2001). Information technology enables instructors to meet the needs of diverse students when, where, and how they want to learn. IT-based strategies can be used to improve learning, in part at least, by permitting instructors or curriculum designers to create individualized learning environments that can serve students in ways that they can use to greatest advantage. One challenge with distance learning programs is to ensure that students gain at least the same quality of educational experiences as traditional campus based students. The application of "software agents," computer systems to which a human user can delegate tasks (Wooldridge and Jennings, 1995), has led to research into the ways in which agents may be used to support students online. Software agents may be used to help teach, for example by affording access to learning or modeling modules or virtual environments. Software agents can be made to work actively and adapt to users, they can simulate some of the roles of instructors, they can monitor progress, help organize students' work and provide feedback for themselves and for instructors. Whatley (2004) reports on an agent system, the Guardian Agent, designed to assist student teams working online to search the Internet, share information with other team members and undertake group projects online. The concept of an agent originates from human agents that provide services, such as a travel agent. These agents have specialist skills, access to relevant information, contacts for obtaining information and are focused on a particular task. In the same way software agents are autonomous systems that work on behalf of a user. They exhibit the ability to recognize 
what the user needs to accomplish and react to the user's input.

\section{IT-Based Assessment}

Information technology is especially well suited for assessment purposes, because it can readily be designed to track user actions and provide instant feedback for the student and instructor. In her description of the SemNet software, Fisher notes that "... it doesn't make sense to teach for conceptual understanding unless one also tests for conceptual understanding" (Fisher, 2000, p. 197). SemNet is one of a number of software programs designed for assessing student learning. Applied to third graders, middle school children, and college students, it works by permitting the learner to construct a semantic network or conceptual graph about any descriptive or declarative domain of knowledge. SemNet is but one of many software environments designed to assess aspects of learning (see e.g. Mintzes et al., 2000). When students interact with educational software, that software can be designed to collect detailed records of student activities and responses that provide information about their learning. Many aspects of cognition or level of expertise have been difficult to assess with traditional testing methods. For example, it is not easy to assess problem-solving strategies with paper-and-pencil tests. By contrast, software can present complex, realistic, open-ended problems for solution and simultaneously collect evidence about how the student goes about solving the problem (Horwitz, 1999; NRC, 2001). An important question is whether learning accomplished within the context of a computer-based environment gives knowledge about the domain being represented or only about the computer-based environment. This question is raised by the puzzling finding that students often fail to transfer knowledge gained on the computer to performance on paper-and-pencil assessments (Horwitz, 1999).

If the studies reviewed above offer convincing ideas about how science education might be improved: by transforming lectures into engaging inquiry experiences for students, by involving students in direct investigations, and by better use of the tools of information technology, then why are these changes not already sweeping through the higher education community? What do studies find to be the barriers to educational change? And what means are at hand to overcome those barriers?

\section{WHAT CHANGES ARE NEEDED IN INSTITUTIONS OF HIGHER LEARNING TO ENCOURAGE FACULTY TO IMPROVE SCIENCE TEACHING?}

Why do scientists, trained to demand evidence for every aspect of their research, enter their classrooms as instructors using teaching methods that are supported only by intuition and habit? There are many reasons. Most scientists are unaware of the data about the effectiveness of teaching methods, despite increasing frequency of publications in the professional scientific literature of each discipline (e.g. Crouch and Mazur, 2001; Dancy and Beichner, 2002; Handelsman et al., 2004; Pukkila, 2004). Many distrust the evidence because they see around them colleagues and some students who have flourished in the current educational system. Some distrust the data because educational research uses unfamiliar methods and arguments. Some are intimidated by the challenge of learning new teaching methods, or are afraid that identification as teachers will reduce their credibility as researchers (Boyer, 1990; Shulman, 1993; Cech, 2003). Moreover, faculty members on most campuses see few rewards for efforts to improve their teaching. Indeed, most are likely to face significant disincentives to learn new teaching approaches or to reformulate an introductory course: it requires a large investment of time, and it is a distraction from the focus on research.

To overcome these barriers, many at the forefront of the educational reform movement are calling for the creation of a university-wide culture that encourages change instead of impeding it and for better mechanisms to inform scientists about education research and the instructional resources available to them (NRC, 2003a,b; Handelsman et al., 2004). The scientific community itself-colleges and universities, professional societies, funding agencies - must unite to provide the resources, incentives, and opportunities for faculty to engage in scientific teaching. As noted by Millar (2003), a few pioneers will act without the support of the community, but most educators will wait for the convergence of interacting forces to propel them in a new direction.

How can effective instruction, as defined in the sections above, be promoted within a university culture that is dedicated primarily to research and the advancement of scholarship? In many small liberal arts colleges and community colleges, substantial progress has been made in instilling a "learning paradigm" culture (Tagg, 
2003), often fostered by organizations such as the American Association of Colleges and Universities SENCER program (http://www.aacuedu.org/SENCER/index.cfm), Project Kaleidoscope (PKAL) (http://www. pkal.org/), and the Preparing Future Faculty program (http://www.preparingfaculty.org/default.htm). In most research-intensive institutions of higher learning there is, instead, a culture that values the activities that lead to cutting-edge research: intense concentration on laboratory or field investigations, on obtaining the grants needed to support that research, and on training graduate students and postdoctoral fellows to extend it. As noted half a century ago by Merton (1957), "On every side the scientist is reminded that it is his role to advance knowledge.... Recognition and esteem accrue to those... who have made genuinely original contributions to the common stock of knowledge" (p. 642). Furthermore, the culture that rewards research productivity more than teaching effectiveness has changed little on many campuses in the past half century (NRC, 2003a). Tobias (1992) notes that even if an energetic and ardent fledgling campus counter-culture of educational reform appears, progress is always slow. "They shake but nothing moves" (p. 16). Even the students can present barriers. No matter how discredited is the traditional lecture when used as a primary instructional approach (Honan, 2002), many faculty are confronted by students who resist new teaching strategies; presumably because it is harder work to understand than to memorize (Garvin, 2003; Powell, 2003). Little wonder then that those educational reformers who advocate that instructors enlarge their priorities to include major improvements in undergraduate teaching have met resistance.

As noted earlier in this essay, forces from both within and outside higher education are pressing for change in post-secondary science instruction. The corporate world is demanding a highly trained workforce that can think analytically, solve problems, work in groups, and apply quantitative methods. As improved secondary science curricula such as Project-based Science (http://www.umich. edu/ pbsgroup/) and the Physics First programs (http://members. aol.com/ physicsfirst/) are adopted by more and more high schools, greater numbers of students will begin to enter college with better science and mathematics backgrounds and with the expectations for far more than textbook driven lectures in their science courses. In recent reports, panels of distinguished scientists and educators have suggested ways to reformulate incentives for faculty to adopt improved instructional strategies (e.g. NRC, 2003b; Handelsman et al., 2004). Some of the methods by which presidents, deans, and department chairs might encourage faculty to learn new effective approaches to teaching include the following.

(1) Use their visible positions to exhort faculty, staff, and administrators to unite in the reform of science education and dispel the notion that excellence in teaching is incompatible with first-rate research.

(2) Encourage collegial, supportive assessment efforts at the departmental level to provide evidence about the quality of instruction, especially in lower division science courses. There are several effective teaching evaluation instruments such as the Reformed Teaching Observation Protocol (RTOP, at http://physicsed.buffalostate. edu/AZTEC/RTOP/ RTOP full/) that are well validated and informative.

(3) Match the faculty incentive system with the need for reform. Tenure policies, sabbaticals, awards, adjustments in teaching responsibilities and administrative support should be used to reinforce those who seek time to improve their teaching based on deep thinking and reflection, research and adaptation of courses. Rewards should go to those who are teaching with research-tested and successful strategies, learning new methods, or introducing and analyzing new assessment tools in their classrooms. Providing instructors with a period of reduced teaching load and rewarding efforts to improve instruction by allotting release time, summer stipends, or sabbatical leave, and the extra resources required for consultation with colleagues and education experts can be important incentives.

(4) Create more vehicles for educating faculty, graduate students, post-doctoral fellows, and staff in tested, effective pedagogy. Incorporate education about teaching and learning into graduate training and faculty development programs and fully integrate these initiatives into the educational environment and degree requirements.

(5) Publicly announce the establishment of a centralized fund for educational improvement in the dean's office; this can send a 
powerful message regarding a change in emphasis of institutional values.

(6) Consider efforts by faculty who engage students in learning-centered courses as important activities in matters of tenure, promotion, and salary decisions, and modify promotion and tenure policies in ways that motivate faculty to spend time and effort on developing new teaching methods or redesigning courses to be more learner centered.

(7) In hiring new faculty and post-doctoral fellows, place greater emphasis on awareness of new teaching methods, perhaps earmarking a small portion of research support packages to fund attendance of incoming instructors and post-docs at teaching workshops.

(8) Consider faculty time spent in redesign of introductory courses or in research focused on teaching and learning a discipline as evidence of productivity as a teacher-scholar.

(9) Encourage lecture-track faculty, a rapidly expanding group at many research universities, to enhance their teaching skills, to serve as valued course directors, and to collaborate as educational experts with tenure-track instructors.

An important role in improving science education that should not be overlooked can be played by funding agencies, both governmental and private. Since its inception, the leadership of NSF has taken care to combine research and education in their programs and grant offerings. Examples include the Faculty Early Career Development (CAREER) program, the Distinguished Teaching Scholars (DTS) program, Biocomplexity in the Environment (BE): Integrated Research and Education in Environmental Systems, the Graduate Teaching Fellows in K-12 Education (GK-12) program, and the Mathematics and Science Partnerships (MSPs). To further its support of science education reform NSF has recently mandated that every proposal for scientific research must be reviewed according to two criteria: "intellectual merit" and "broader impact." Examples of the latter category emphasize education: Does the research promote teaching, training, and learning? How will it improve science education? Does it include undergraduate or precollege students as participants? Will the results contribute to educational materials or databases? Such questions, aimed specif- ically at investigators, serve to highlight the importance of instruction in the academic culture.

Similar pressures are being applied by private foundations. The largest privately funded education initiative of its kind in the United States is the Howard Hughes Medical Institute's grants program which supports programs to enhance science education for students at all levels, from the earliest grades through advanced training. Since 1988 HHMI has awarded more than $\$ 1.2$ billion in grants to biomedical research institutions, universities, and colleges to support innovative science education programs at the pre-kindergarten to 12th-grade and undergraduate levels. With direct impact on college faculty is the HHMI Professor's program. The HHMI professors are leading research scientists who also are deeply committed to making science more engaging for undergraduates. Their innovative approaches to teaching infuse undergraduate science with the excitement and rigor of scientific research. The program is becoming a model for fundamental reform of the way undergraduate science is taught at research universities. These programs seek to encourage young people's interest in science, prepare them for sciencerelated careers, and increase science literacy among all students, including non-science majors.

While faculty members can be encouraged by their dean or their funding agency to initiate educational innovation, the culture of their departments and their institution plays a powerful role in enabling or inhibiting the success of such innovation and its expansion to other members of the faculty. Numerous reports have appeared describing efforts to assist institutions of higher education with programs of instructional change. In 1995, the American Council on Education (ACE) launched the Project on Leadership and Institutional Transformation with 26 public and private institutions. The goal was to help campus change-leaders articulate a comprehensive agenda for the improvements they sought. After six years of observations, visits, conversations, meetings and reports, Eckel (2002) offers the insight that the change process requires three key tasks: (1) creating institution-wide momentum and energy for change; (2) removing barriers to change and elements that reinforce the status quo; and (3) helping people to think differently and adopt new mental models. Other resources to support such reform efforts have included intercampus faculty networks and national support organizations such as Chautauqua (http://www. chautauquainst.org/education.html), and the SENCER, PKAL, 
and PFF programs mentioned above. An example of a way to enhance teaching skills and career development for post-doctoral fellows is the NIH's IRACDA program (http://www.nigms.nih.gov/minority/iracda institutions.html).

If the entire academic community succeeds in marshalling its collective will to reform science education, the results could be sweeping. The idealized goal that many education reformers might aspire to is described in detail in The Learning Paradigm College by JohnTagg (2003). Faculty would become experimentalists in their classrooms (Dancy and Beichner, 2002) just as they are in their laboratories and field work. They would bring rigor and enthusiasm of research to their teaching, and continue developing as teachers throughout their careers. Introductory science courses would engage students and encourage them to take more science classes. More non-science majors would enter society with respect for the scientific endeavor and with a grasp of how scientific information is obtained and used. A greater range and diversity of students would become science majors who, through their early research experiences, would feel the allure of experimental science and the thrill of discovery. As Handelsman et al. (2004) note, the end result - a scientifically literate society and a reinvigorated research enterprize - could be far-reaching. It could even be revolutionary.

\section{ACKNOWLEDGMENTS}

Thanks to Arri Eisen, Karen Falkenberg, Diana Toebbe and Pat Marsteller (all of Emory University) and Bill Wood (University of Colorado) for helpful comments on this article.

\section{REFERENCES}

Allen, D., and Tanner, K. (2003a). Approaches to cell biology teaching: Learning content in context-Problem-based learning. Cell Biology Education 2(2): 73-81.

Allen, D., and Tanner, K. (2003b). Approaches to cell biology teaching: Mapping the journey-concept maps as signposts of developing knowledge structures. Cell Biology Education 2(3): 133-136.

Ambrose, B. S., Heron, P. R. L., Vokos, S., and McDermott, L. C. (1999). Student understanding of light as an electromagnetic wave: Relating the formalism to physical phenomena. American Journal of Physics 67(10): 891898.

Arons, A. B. (1983). Achieving wider scientific literacy. Daedalus 112: $91-102$

Berg, C. A. R., Bergendahl, V. C. B., and Lundberg, B. K. S. (2003). Benefiting from an open-ended experiment? A com- parison of attitudes to, and outcomes of, an expository versus an open-inquiry version of the same experiment. International Journal of Science Education 25(3): 351-372.

Bligh, D. A. (2000). What's the Use of Lectures? Jossey-Bass, San Francisco.

Boyer, E. L. (1990). Scholarship Reconsidered: Priorities of the Professoriate, Carnegie Foundation for the Advancement of Teaching, Princeton, NJ.

Boyer Commission on Educating Undergraduates in the Research University. (1998). Reinventing Undergraduate Education: A Blueprint for America's Research Universities, Carnegie Foundation for the Advancement of Teaching, Menlo Park, CA. Retrieved January 21, 2003 from: http://naples.cc.sunysb.edu/Pres/boyer.nsf/.

Breuer, J. T. (1997). Education and the brain: A bridge too far. Educational Researcher 26(8): 4-16.

Cech, T. R. (2003). Rebalancing teaching and research. Science 299: 165 .

Chatterjee, A. (2004). Cosmetic neurology: The controversy over enhancing movement, mentation, and mood. Neurology 63(6): 968-974.

Crouch, C. H., and Mazur, E. (2001). Peer instruction: Ten years of experience and results. American Journal of Physics 69(9): 970-977.

Damasio, A. R. (1999). The Feeling of What Happens: Body and Emotion in the Making of Consciousness, Harcourt, New York.

Dancy, M. H., and Beichner, R. J. (2002). But are they learning? Getting started in classroom evaluation. Cell Biology Education 1(3): 87-94.

Deardorf, J. (2004). To many, using Ritalin to think faster looks like cheating, Billings Gazette. Retrieved January 9, 2005 at http://www.billingsgazette.com/index.php?id=1\&display= rednews/2004/04/14/build/health/40-ritalin.inc.

DebBurman, S. K. (2002). Learning how scientists work: Experiential research projects to promote cell biology learning and scientific process skills. Cell Biology Education 1(4): 154172.

Dede, C. (2000). Emerging Technologies and Distributed Learning in Higher Education, at http://www.virtual.gmu.edu/SS research/cdpapers/hannapdf.htm.

Donald, J. (2002). Learning to Think: Disciplinary Perspectives, Jossey-Bass, San Francisco.

Duch, B., Gron, S., and Allen, D. (2001). The Power of ProblemBased Learning, Stylus, Sterling, VA.

Dwyer, F. M. (1972). The effect of overt responses in improving visually programmed science instruction. Journal of Research in Science Teaching 9: 47-55.

Ebert-May, D., Brewer, C., and Allred, S. (1997). Innovation in large lectures-teaching for active learning. Bioscience 47: 601-607.

Eckel, P. D. (2002). Institutional transformation and change: Insights for faculty developers. In Lieberman, D. (Ed.), To Improve the Academy: Resources for Faculty, Instructional, and Organizational Development, Anker, Bolton, MA.

Edwards, N. (1996). Computer-based laboratory simulations: Evaluations of students' perceptions. Association for Learning Technology Journal 4(3): 41-53.

Fisher, K. M. (2000). SemNet software as an assessment tool. In Mintzes, J. J., Wandersee, J. H., and Novak, J. D. (Eds.), Assessing Science Understanding: A Human Constructivist View, Academic Press, San Diego, pp. 197-221.

Garvin, D. A. (2003). Making the case: Professional education for the world of practice. Harvard Magazine 106(1): 56-75.

Gee, J. P. (1999). An Introduction to Discourse Analysis: Theory and Method, Routledge, New York.

Gee, J. P. (2003). Language in the science classroom: Academic social languages as the heart of school-based literacy. In Yerrick, R., and Roth, W.-M. (Eds.), Establishing Scientific 
Classroom Discourse Communities: Multiple Voices of Research on Teaching and Learning, Lawrence Erlbaum, Mahwah, NJ.

Gelman, R., and Gallistel, C. R. (2004). Language and the origin of numerical concepts. Science 306: 441-443.

Glenn Commission Report. (2000). Before It's Too Late: A Report to the Nation from the National Commission on Mathematics and Science Teaching for the 21st Century. Retrieved December 15, 2004 from http://www.ed.gov/inits/Math/ glenn/report.pdf.

Gordon, P. (2004). Numerical cognition without words: Evidence from Amazonia. Science 306: 496-499.

Hake, R. R. (1998). Interactive engagement versus traditional methods: A six-thousand student survey of mechanics test data for introductory physics courses. American Journal of Physics 66: 64-74.

Hake, R. R. (2002). Assessment of Student Learning in Introductory Science Courses. 2002 PKAL Roundtable on the Future: Assessment of Student Learning, Duke University. Retrieved December 15, 2004 from http://www.pkal.org/documents/ ASLIS.Hake.060102f.pdf.

Hall, S. S. (2003). The quest for a smart pill. Scientific American 289(3): 54-65.

Halpern, D. F., and Hakel, M. F. (2003). Applying the science of learning to the university and beyond: Teaching for long-term retention and Transfer. Change 35(4): 37-41.

Handelsman, J., Ebert-May, D., Beichner, R., Bruns, P., Chang, A., DeHaan, R. L., Gentile, J., Lauffer, S., Stewart, J., Tilghman, S. M., and Wood, W. B. (2004). Scientific teaching. Science 304: 521-522.

Heron, P. R. L., Loverude, M. E., Shaffer, P. S., and McDermott, L. C. (2003). Helping students develop an understanding of Archimedes' principle. II. Development of research-based instructional materials. American Journal of Physics 71(11): 1188-1195.

Hestenes, D., Wells, M., and Swackhamer, G. (1992). Force concept inventory. Physics Teacher 30: 141-158.

Hodson, D. (1993). Re-thinking old ways: Towards a more critical approach to practical work in school science. Studies in Science Education 22: 85-122.

Honan, W. H. (2002). The college lecture, long derided, may be fading. The New York Times (August 14, Section B, p. 7).

Horwitz, P. (1999). Designing computer models that teach. In Feurzeig, W., and Roberts, N. (Eds.), Modeling and Simulation in Science and Mathematics Education, Springer-Verlag, New York, pp. 179-196.

Kandel, E. R., Schwartz, J. H., and Jessell, T. H. (2000). Principles of Neural Science, 4th edn., McGraw-Hill, New York.

Kardash, C. M. (2000). Evaluation of an undergraduate research experience: Perceptions of undergraduate interns and their faculty mentors. Journal of Educational Psychology 92(1): 191-201.

King, A. (1994). Inquiry as a tool in critical thinking. In Halpern, D. F. (Ed.), Changing College Classrooms: New Teaching and Learning Strategies for an Increasingly Complex World, Jossey-Bass, San Francisco, pp. 13-38.

Klymkowsky, M. W., Garvin-Doxas, K., and Zeilik, M. (2003). Bioliteracy and teaching efficacy: What biologists can learn from physicists. Cell Biology Education 2(3): 155-161.

Koch, C., and Laurent, G. (1999). Complexity and the nervous system. Science 284: 96-98.

Laurillard, D. (2002). Rethinking University Teaching: A Conversational Framework for the Effective Use of Learning Technologies, 2nd edn., Routledge, New York.

Laws, P. W. (1997). Workshop Physics Activity Guide: Core Volume with Module 1, Wiley, New York.

Lawson, A. E. (2003). Using the RTOP to evaluate reformed science and mathematics instruction. In McCray, R. A., DeHaan, R. L., and Schuck, J. A. (Eds.), Improving Under- graduate Instruction in Science, Technology, Engineering, and Mathematics: Report of a Workshop, Center for Education, Division of Behavorial and Social Sciences and Education, The National Academies Press, Washington, DC, pp. 89100.

Loverude, M. E., Kautz, C. H., and Heron, P. R. L. (2003). Helping students develop an understanding of Archimedes principle. I. Research on student understanding. American Journal of Physics 71(11): 1178-1187.

Mazur, E. (1997). Peer Instruction: A User's Manual, PrenticeHall, Upper Saddle, NJ.

McDermott, L. C. (1974). Combined physics course for future elementary and secondary school teachers. American Journal of Physics 42: 668-676.

McDermott, L. C. (1991). Millikan Lecture 1990: What we teach and what is learned-closing the gap. American Journal of Physics 59: 301-315.

McDermott, L. C. (2001). Oersted Medal Lecture 2001: Physics education research - the key to student learning. American Journal of Physics 69(11): 1127.

McDermott, L. C., and Redish, E. F. (1999). Resource Letter PER1: Physics Education Research, available at http://www.phys. washington.edu/groups/peg/rl.htm.

Merton, R. K. (1957). Priorities in scientific discovery. American Sociological Review 22(6): 635-659.

Mervis, J. (2003). Scientific workforce: Down for the count? Science 300(5622): 1070-1074

Millar, S. B. (2003). Effecting faculty change by starting with effective faculty: Characteristics of successful STEM education innovators; National Research Council. (2003). In McCray, R. A., DeHaan, R. L., and Schuck, J. A. (Eds.), Improving Undergraduate Instruction in Science, Technology, Engineering, and Mathematics: Report of a Workshop, Center for Education, Division of Behavioral and Social Sciences and Education, The National Academies Press, Washington, DC, pp. 101-117.

Mintzes, J. J., Wandersee, J. H., and Novak, J. D. (Eds.) (2000). Assessing Science Understanding: A Human Constructivist View, Academic Press, San Diego.

Miyashita, Y. (2004). Cognitive memory: Cellular and network machineries and their top-down control. Science 306(5695): $435-440$.

Mulford, D. R., and Robinson, W. R. (2002). An inventory for alternate conceptions among first-semester general chemistry students. Journal of Chemical Education 79(6): 739744 .

Musallam, S., Corneil, B. D., Greger, B., Scherberger, H., and Andersen, R. A. (2004). Cognitive control signals for neural prosthetics. Science 305(5681): 258-262.

National Commission on Excellence in Education. (1983). A Nation at Risk: The Imperative for Educational Reform, US Department of Education, Washington, DC.

National Research Council. (1997). Science Teaching Reconsidered: A Handbook, Committee on Science Education, Center for Science, Mathematics, and Engineering Education, National Academy Press, Washington, DC.

National Research Council. (1999a). How people learn: Bridging research and practice. In Donovan, M. S., Bransford, J. D., and Pellegrino, J. W. (Eds.), Committee on Learning Research and Educational Practice, Commission on Behavioral and Social Sciences and Education, National Academy Press, Washington, DC.

National Research Council. (1999b). Transforming Undergraduate Education in Science, Mathematics, Engineering, and Technology, Committee on Undergraduate Science Education, Center for Science, Mathematics, and Engineering Education, National Academy Press, Washington, DC.

National Research Council. (2000). How people learn: Brain, mind, experience and school, expanded edition. In Bransford, 
J. D., Brown, A. L., and Cocking, R. R. (Eds.), Committee on Developments in the Science of Learning; and Donovan, M. S., Bransford, J. D., and Pellegrino, J. W. (Eds.), Committee on Learning Research and Educational Practice, Commission on Behavioral and Social Sciences and Education, National Academy Press, Washington, DC.

National Research Council. (2001). Knowing what students know: The science and design of educational assessment. In Pellegrino, J. W., Chudowsky, N., and Glaser, R. (Eds.), Committee on the Foundations of Assessment, Commission on Behavioral and Social Sciences and Education, National Academy Press, Washington, DC.

National Research Council. (2002a). BIO2010: Transforming Undergraduate Education for Future Research Biologists, Committee on Undergraduate Biology Education to Prepare Research Scientists for the 21st Century, Board on Life Sciences, National Academy Press, Washington, DC.

National Research Council. (2002b). In Hilton, M. (Ed.), Enhancing Undergraduate Learning with Information Technology: A Workshop Summary, Center for Education, National Academy Press, Washington, DC.

National Research Council. (2003a). Evaluating and improving undergraduate teaching in science, technology, engineering, and mathematics. In Fox, M. A., and Hackerman, N. (Eds.), Committee on Recognizing, Evaluating, Rewarding, and Developing Excellence in Teaching of Undergraduate Science, Mathematics, Engineering, and Technology, Center for Education, Division of Behavorial and Social Sciences and Education, The National Academy Press, Washington, DC.

National Research Council. (2003b). Improving undergraduate instruction in science, technology, engineering, and mathematics: Report of a workshop. In McCray, R. A., DeHaan, R. L., and Schuck, J. A. (Eds.), Center for Education, Division of Behavioral and Social Sciences and Education, The National Academy Press, Washington, DC.

National Research Council. (2003c). Envisioning a 21st Century Science and Engineering Workforce for the United States: Tasks for University, Industry, and Government, Government-University-Industry Research Roundtable (GUIRR), The National Academy Press, Washington, DC.

National Science Board. (2004). A Companion to Science and Engineering Indicators 2004, NSB 04-07. Retrieved October 20, 2004 from www.nsf.gov/sbe/srs/nsb0407/start.htm.

Novak, J. D. (2002). Meaningful learning: The essential factor for conceptual change in limited or inappropriate propositional hierarchies leading to empowerment of learners. Science Education 86: 548-571.

Ogborn, J. (1999). Modeling clay for thinking and learning. In Feurzeig, W., and Roberts, N. (Eds.), Modeling and Simulation in Science and Mathematics Education, Springer-Verlag, New York, pp. 5-37.

Pica, P., Lemer, C., Izard, V., and Dehaene, S. (2004). Exact and approximate arithmetic in an Amazonian indigene group. Science 306: 499-503.

Powell, K. (2003). Spare me the lecture. Nature 425: 234-236.

Project Kaleidoscope. (2002). Recommendations for Action in Support of Undergraduate Science, Technology, Engineering, and Mathematics: Report on Reports, Author, Washington, DC.

Pukkila, P. J. (2004). Introducing student inquiry in large introductory genetics classes. Genetics 166(1): 11-18.

Redish, E. F. (1999). Millikan Lecture 1998: Building a science of teaching physics. American Journal of Physics 67(7): 562-573.

Redish, E. F. (2003). Teaching Physics with the Physics Suite, Wiley, Hoboken, NJ.

Reinvention Center at Stony Brook. (2001, May). Reinventing Undergraduate Education: Three Years After the Boyer Report. Retrieved January 21, 2003 from www.sunysb.edu/ reinventioncenter/boyerfollowup.pdf.
Roth, W.-M., and Duit, R. (2003). Emergence, flexibility, and stabilization of language in a physics classroom. Journal of Research in Science Teaching 40(9): 869-897.

Roussev, B., and Rousseva, Y. (2004). Active learning through modeling: Introduction to software development in the business curriculum. Decision Sciences 2(2): 121142 .

Schwartz, M. S., and Fischer, K. W. (2003). Building vs. borrowing: The challenge of actively constructing ideas in post-secondary education. Liberal Education 89(3): 22-29.

Seymour, E., and Hewitt, N. M. (1997). Talking About Leaving: Why Undergraduates Leave the Sciences, Westview Press, Boulder, CO.

Seymour, E., Hunter, A.-B., Laursen, S. L., and Deanton, T. (2004). Establishing the benefits of research experiences for undergraduates in the sciences: First findings from a threeyear study. Science Education 88: 493-534.

Shulman, L. S. (1993). Teaching as community property: Putting an end to pedagogical solitude. Change 25(6): 6-7.

Silva, T. D. N., Aguiar, L. C. daC., Leta, J., Santos, D. O., Cardoso, F. S., Cabral, L. M., Rodrigues, C. R., and Castro, H. C. (2004). Role of the undergraduate student research assistant in the new millennium. Cell Biology Education 3(4): 235-240.

Spitulnik, M. W., Krajcik, J., and Soloway, E. (1999). Construction of models to promote scientific understanding. In Feurzeig, W., and Roberts, N. (Eds.), Modeling and Simulation in Science and Mathematics Education, Springer-Verlag, New York, pp. 70-94.

Strangman, N., and Hall, T. (2003). Virtual Reality/Computer Simulations: Curriculum Enhancement, National Center on Assessing the General Curriculum. Retrieved January 9, 2005 at http://www.cast.org/ncac/index.cfm?i=4832.

Tagg, J. (2003). The Learning Paradigm College, Anker, Bolton, MA.

Tobias, S. (1992). Revitalizing Undergraduate Science: Why Some Things Work and Most Don't, Research Corporation, Tucson, AZ.

Tully, T., Bourtchouladze, R., Scott, R., and Tallman, J. (2003). Targeting the CREB pathway for memory enhancers. Nature Reviews: Drug Discovery 2(4): 267-277.

Twigg, C. (2003). Improving quality and reducing cost: Designs for effective learning. Change 35(4): 23-29.

Twigg, C. A. (2001). Innovations in On-Line Learning: Moving Beyond No Significant Difference, The Pew Learning and Technology Program. Retreived October 20. 2004 from http:// www.center.rpi.edu/ PewSym/ Mono4.html \#Anchor47857.

Udovic, D., Morris, D., Dickman, A., Postlethwait, J., and Wetherwax, P. (2002). Workshop biology: Demonstrating the effectiveness of active learning in an introductory biology course. Bioscience 52(3): 272-281.

Whatley, J. (2004). An agent system to support student teams working online. Journal of Information Technology Education 3: 53-63.

Wood, W. B. (2003). Inquiry-based undergraduate teaching in the life sciences at large research universities: A perspective on the Boyer Commission Report. Cell Biology Education 2(2): 112-116.

Woods, H. A., and Chiu, C. (2003). Wireless Response Technology in College Classrooms. Technology Source. Retrieved October 20, 2004 from http://ts.mivu.org/default.asp?show= article\&id $=1045$.

Wooldridge, M. J., and Jennings, N. R. (Eds.) (1995). Intelligent Agents, Springer-Verlag, Berlin.

Wright, J. C., Millar, S. B., Kosciuk, S. A., Penberthy, D. L., Williams, P. H., and Wampold, B. E. (1998). A novel strategy for assessing the effects of curriculum reform on student competence. Journal of Chemical Education 75(8): 986992. 